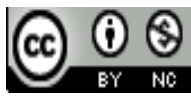 \\ Jurnal Terapan Manajemen dan Bisnis is licensed under \\ A Creative Commons Attribution-Non_Commercial 4.0 International License.
}

\title{
THE CONCEPT OF THE STREET VENDORS' MANAGEMENT IN THE BORDER AREA
}

\author{
Veneranda Rini Hapsari ${ }^{1)}$, Benedhikta Kikky Vuspitasari ${ }^{2)}$, Deffrinica ${ }^{3)}$ \\ 1) STIM Shanti Bhuana, Bengkayang, Indonesia \\ E-mail: rini@shantibhuana.ac.id \\ 2) STIM Shanti Bhuana, Bengkayang, Indonesia \\ E-mail: kikky@shantibhuana.ac.id \\ 3) STIM Shanti Bhuana, Bengkayang, Indonesia \\ E-mail: deffrinica@shantibhuana.ac.id
}

\begin{abstract}
This study aims to determine how the concept of street vendors in Bengkayang Regency, so as to improve the image of the region. The research method uses descriptive qualitative methods. Research location in Bengkayang Regency. The object of this study is the street vendors, which is one of the jobs using the roadside area to sell, as well as the street vendors in Bengkayang Regency. Initially, the street vendors sell at night in the terminal area, but because the terminal will build a shop, the street vendors moved to the Dekranasda area. In these areas it was felt rather quiet of the buyer, so the street vendors moved to sell at the edge of the roadside shophouse that was closed. Thus actually disturbing the view of Bengkayang Regency city planning. But it cannot blame these street vendors either, because it is their livelihood and indirectly adds to regional income. The results of this study are a form of business facilities that harmonious and memorable transparent street vendors so as not to interfere with the visual aesthetics of the corridors on the road, so as to make the road neat and attractive.
\end{abstract}

Keywords: Concept; Street Vendors; Management; Border Area

\section{Introduction}

At present, it tends to be difficult to find work, as is the case in Bengkayang Regency which is a border area, and in this area, there are many settlements, which come from many different economic and social backgrounds. The population in this area, especially the local community, especially in Bengkayang sub-district tends to want to have a job as a civil servant or as a private employee, while the availability to become a civil servant is limited. And economic needs continue to increase, causing people to start looking for ways to get work. So from the problem of limited work, there are people who have their own businesses with minimal capital, one of which is as a street vendor, which is quite potential for people who do not have sufficiently high education, low capital and have the willingness to work as a street vendor will be applicable to that person or society.

This street vendor activity has been going on for a long time. Initially, the location of the street vendor's activities was in and around the terminal, the traders' activities started at 
night until dawn and were temporary because during the day the place was used for traffic activities. Trading on the streets has become a popular alternative to working. This is related to its flexible characteristics (easy in and out), the required capital is relatively small, and does not require complicated procedures. Because the shophouses will be built inside the terminal, the street vendors are moved by the Regional Government to the location of the Regional National Crafts Council, but because the area is empty of visitors and buyers, the street vendors choose to sell around the outside of the terminal, on the edge of the area. the edge of the shophouse, the beginning of the previous street vendor, initially from 10 wagon stands to approximately 50 current car wagon stands. Thus it can be said there is an increase in street vendors and in other words that there is an increase in entrepreneurship in society.

Based on the results of preliminary observations, found several problems or problems that arise from the street vendors, namely how the concept of street vendors in Bengkayang Regency, so as to improve the image of the region. So this study aims to determine the concept of street vendors so that it is expected to improve the image of the region in Bengkayang Regency.

Bengkayang Regency is one of the $3 \mathrm{~T}$ regions (Behind, Outermost, and Foremost). Bengkayang Regency itself is one of the regencies that has a very wide area in the province of West Kalimantan. The location of Bengkayang Regency which borders directly with neighboring countries such as Malaysia and Brunei Darussalam makes Bengkayang Regency a very strategic area (Situmorang, 2019: 77). As a haven for people who are going to the district of Landak, Singkawang Municipality or who will travel to neighboring Malaysia, so that the street vendors who trade have considerable influence because the people who are transiting at the passing time to eat, thus bringing pretty good income to the street vendors. Most street vendors offer their merchandise, especially in front of closed shophouses, with scheduled activities at night until dawn, but even so, it still causes the edge of the road as a public space to lose its function with the existence of these street vendors.

Previous research on the number of street vendors in Yogyakarta and Sleman which brought a lot of regional income, but on the other hand the activities of street vendors disturbed the public space area, so the research aims to find out the arrangement of traders in accordance with the spatial layout of the public area so that it is expected to become a model for traders in Yogyakarta and Sleman (Puspitasari, 2010). In addition to these studies, there are also studies such as the efforts of local governments to beautify the city by arranging the presence of street vendors, when on the one hand the existence of street vendors is recognized as an economic potential that cannot be underestimated. Street hawkers are able to absorb a significant amount of labor and provide the necessities of life for the community. But another thing is the existence of street vendors considered disturbing the beauty and order of the City environment. This is what makes the government intervene in this issue. So seeing the dilemma in structuring street vendors, a strategy is needed in structuring street vendors to stay afloat and not interfere in city planning, considering that street vendors also make a significant contribution to Local Revenue (PAD) (Purnawati, 2016).

So, therefore, researchers feel it is important to examine the arrangement of street vendors in entrepreneurship in the border region in Bengkayang Regency. On the other hand regarding the existence of street vendors still want to run their businesses to meet the needs of daily life, which indirectly also supports the regional economy, but on the other hand, there needs to be a pattern of structuring the urban spatial function, so that in this case means the street vendors continue to carry out their eyes livelihood without disrupting the spatial functions in the area. So from the dilemmatic condition, it is necessary to intervene from the local government to organize the existence of street vendors who sell in the public space area. 
Based on this background, the writing of this research can formulate problems relating to street vendors to realize the Bengkayang Regency spatial function, namely how the concept of street vendors in the Bengkayang Regency area, so as to improve the image of the region.

\section{Literature Review}

A. Concept

According to Umar (2004: 51), "Concepts are a number of theories relating to an object. The concept was created by classifying and grouping certain objects that have the same characteristics ". Street Vendors (PKL) are traders who in their business use facilities that are easily dismantled/moved and use parts of the road/sidewalk, and places for public use that is not intended for business places or other places that do not belong to them. The formula indicates that street vendors are distinguished from other traders based on the type of designation and ownership status of their business location, not based on their capital strength, work methods or legal status. The term street vendors actually already existed from the Raffles era which is derived from the term 5 feet which means the lane is five feet wide. In America, this kind of merchant is called Hawkers who have an understanding of people who offer goods and services for sale in public places, especially on roadsides and sidewalks. (McGee and Yeung, 1977: 25).

\section{B. Street Vendors}

The Definition of Street Vendors According to Karafir in Ali and Alam (2012: 186): "street vendors are small traders who sell in public places such as street parks, parks, emperor shops and market markets without permission from the government". Meanwhile, according to Permadi (2007), street vendors or in short ordinary street vendors are also interpreted as a term to refer to merchants who use carts, the term is often interpreted because the number of traders there are five legs, five feet are two trader feet plus three "legs" of wagons (three wheels or two wheels and one foot).

According to McGee and Yeung (1977: 25), street vendors have the same meaning as "hawkers", which are defined as people who peddle goods and services for sale in a place that is a space for public use, especially on the roadside and sidewalks. Because of the unavailability of informal urban spaces for street vendors, street vendors use public spaces, such as roads, sidewalks, city parks, above drainage channels, river banks to carry out their activities. The use of public space usually occurs in strategic places such as between formal city activities. Not accommodating street vendors in urban space, causing patterns and structures of modern and traditional cities to blend into one, causing a contrasting appearance. Nan magnificent modern buildings side by side with simple buildings and even tend to be slums. The dualistic physical appearance occurs in all urban spaces, especially in the functional areas of the city.

According to Widigdo and Zain (2013: 117), physical means of street vendors can be grouped as follows:

1) Kiosk

Traders who use this form of the facility are categorized as resident traders because physically this type cannot be moved. Usually, a semi-permanent building made of boards.

2) Semi-permanent stalls

Consisting of several carts arranged in a row equipped with a long table and bench. The shape of this facility is covered by tarpaulin or plastic which is impermeable to water. Street vendors in the form of this facility are categorized as permanent street vendors and usually sell food and drinks. 
3) Wheelbarrow/Stroller

There are 2 types of trading facilities, namely a covered wagon/cart as protection for merchandise from the influence of heat, dust, rain, etc., and a non-roofed wagon/cart. This facility is categorized as permanent and non-permanent street vendors. Usually to peddle food, drinks, and cigarettes.

4) Squat/Table

This form of trading means can be roofed or roofed. Tools like this are categorized as permanent street vendors.

5) Mat

Traders peddle their wares on cloth, mats, and others to peddle their wares. The form of this facility is categorized as semi-permanent street vendors and is generally often found in the type of grocery items.

6) Basket

This tool is used by mobile traders (mobile hawkers) or semi-permanent using one or two baskets by means of carrying. This form is intended to make merchandise easy to carry around.

\section{Management}

In the business activity, management is needed to manage a business so that it can run well, in accordance with the plans and goals. In the opinion of Siagian (2008: 2) referred to management is an effort or cooperation of two or more people carried out to achieve a predetermined goal. So that in this case the activity for street vendors also requires good and directed management, so that the street vendors and the local government can coordinate with each other so that the activity can run well according to the rules of the local government.

\section{Border}

State border areas are regency/city areas that are geographically and demographically directly adjacent to neighboring countries and/or the high seas. The border area consists of land and sea border areas, which are widely spread with diverse typologies, ranging from the interior to the small front / outermost islands (Bappenas, 2010: 63). Boundary area, in essence, has a very vital meaning and strategic, at least when viewed from three points of view, namely: defense-security, economy-trade, and socio-culture (Koespramoedyo, 2003: 9).

\section{Research Methods}

This study uses primary data and secondary data, primary data obtained directly from the speakers and respondents related to the study. For research in the field using observation, interviews. According to Sugiyono (2013), research methods are basically scientific ways to obtain data with specific purposes and uses. The location of the study was determined by the method of purposive sampling, namely in Bengkayang Regency, with consideration because in that place many street vendors sell in public areas so that the area became less tidy and not in accordance with its function. So from these conditions, there needs to be handling and policies from local governments to manage these problems. Respondents in this study were street vendors, who were selling in front of the shop. Data collection tools used in this study such as interviews. Interviews are tailored to developments and theories related to street vendors. 


\section{Results and Discussion}

From this research, there is a concept that must be carried out by local governments to regulate street vendors, because the government plays an important role in regulating these activities. The concept is a unified understanding of a thing or problem that is formulated. In formulating we must be able to explain it according to its purpose. So the purpose of the research is to find out the concept of street vendors in Bengkayang Regency so that it can improve the image of the region.

A street vendor is someone who has a business using the roadside to sell. Besides street vendors are important livelihoods for these sellers, on the other hand, the place used to sell is a public area. So with these conditions, the local government must get involved with the problem. So that the street vendors can still sell to supplement their income and finance their daily needs and the government can manage the area well, without sacrificing the livelihoods of the street vendors. The concept of structuring for public space greatly affects the welfare of these street vendors.

To realize the efficiency of public areas in the district, as a place for economic activity, there needs to be an arrangement in the management of space or places effectively and optimally. The concept of structuring the place according to its function must involve the local government. Because with the involvement of the local government it will be able to realize the allocation of business premises in accordance with its function so that it can empower the presence of street vendors and indirectly generate income for the region. The growing growth of street vendors is in dire need of local government intervention, due to the current limitations of the local government in providing employment, so that the business of street vendors brings a considerable influence on regional income, although on the other hand, can not be denied, the existence of these street vendors make the side of the road, especially in front of the shop that has been closed at night to make the existence of the road is not in accordance with its function, besides that in terms of providing insufficient parking. Because in practice street vendors have used the function of public facilities so that it can cause discomfort in the function of the road (Tahir, 2016).

According to interviews with street hawkers, street vendors now have access to selling and entrepreneurship, such as the ease of obtaining funds, the manager cooperates with the bank, so that for street vendors who borrow in order to obtain funds, convenience is given by the bank, because there is already a guarantee from the management of street vendors, so street vendors who need funds to develop their businesses can be realized immediately. So from the convenience, making the street vendors have no financial difficulties even some who already have investments in the form of land or houses. So that the existence of street vendors can still be carried out in the sense that traders can still run their businesses, so that they can meet the necessities of life and the government is also helped in terms of reducing the unemployment rate in the region, and indirectly can increase regional income, the local government can provide the solution to the street vendors is by holding coordination and prior socialization to the street vendors, as they are:

1. Concept of Provision of a Place for Sales

The provision of a place that has been provided by the Regional Government, can create a sense of security for street vendors. Because their business or work is noticed and protected by the Regional Government. Although on the other hand, traders certainly expect the provision of a strategic location for their business, so as to produce the income or income as expected. In addition, street vendors can relocate according to article 20 of Permendagri No. 41 of 2012. 


\section{Harmony of Layout Place to Sell}

The purpose of the Regional Government is to create a uniform layout so that it can create harmony and increase the attractiveness of the visitors. The uniformity that can be recommended can be transparent, so it does not interfere with visual aesthetics. The existence of street vendors must have a pattern that can be adapted to the available place or location. It is possible for street vendors' business facilities to use matching colors so as to give a uniform impression. The means of street vendors are recommended to use non-permanent facilities so that pairs can be dismantled because street vendors are conducted at night so that during the day the places provided by the local government can be used and empowered with other business activities.

\section{Retribution}

To implement Bengkayang Regency Regional Regulation No. 5 of 2010 concerning market service levies article 1 paragraph 14. street vendors are individuals who sell on the side of the road or a place determined by the regional government, using a cart, table, tent that must be diverted and/or dismantled after the end of time to sell. Market service levies are levies imposed by regional governments on traders as payment for the use, use and use of kiosks, booths, street stalls in the market area and general trading sites, provided by regional governments and shops owned by individuals or other private entities. Government solutions to street vendors are easier to understand on Fig. 1.

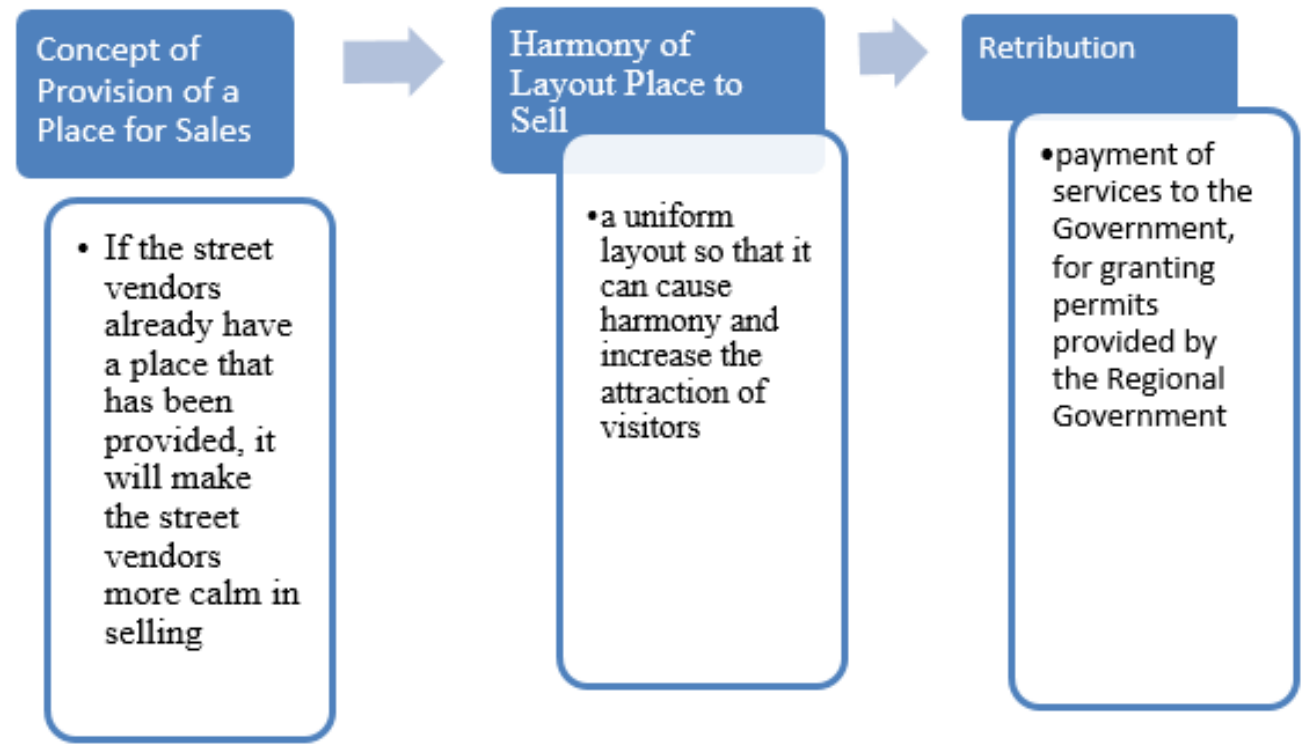

Fig. 1 Government Solutions to Street Vendors

Article 14 paragraph (1) Street vendors who sell by the side of public roads in a market area that uses tents, carts and sell at night are required to display their merchandise from 17.00 to 05.00 a.m., and to maintain the cleanliness of their respective selling areas. In Bengkayang Regency Local Regulation Number 5 the Year 2010, which regulates market service user fees. Basically, street vendors do not mind giving a levy, because with fees they pay-services to the government that provides a place and permission to sell. so that routine levies can provide indirect regional income. So that the concept is related and can be implemented as related to Regulation of the Minister of Home Affairs (Permendagri) Number 41 of 2012 concerning Guidelines for Structuring and Empowering Street Vendors, so that street vendors can keep on trying, supported by the government. 
The structuring concept program for street vendors is a locality program, that is, regions make regulations about the functions and benefits of public places because the regions understand better the conditions of the regions concerned (Azhari, 2017). With the concept of structuring for street vendors, it will make street vendors safer in selling so they can be more focused and can bring in better income. And indirectly can increase revenue for the region. When viewed from an economic and social perspective, the existence of street vendors can have a positive impact on the economic and social aspects, as shown in Fig. 2.

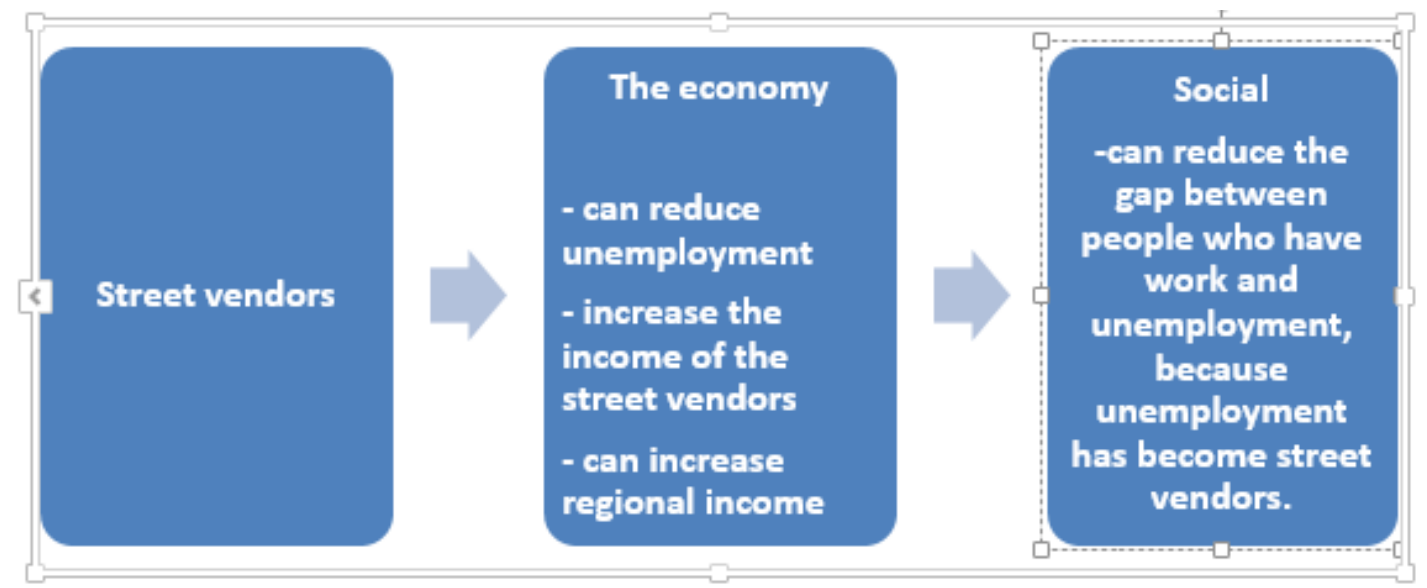

Fig. 2 the Positive Impact of the Existence of Street Vendor on the Economic and Social Aspects

\section{Conclusion}

Based on the results of the analysis and discussion in the study, the role of the Bengkayang Regency Local Government in the administrative concept of structuring street vendors in Jalan Jerandeng was very instrumental, in regulating the order of the street vendors. Because of the existence of street vendors who on the one hand want to get income to meet their daily needs and on the other hand, the place to sell street vendors is public property, so the role of the local government to regulate is clearly needed.

Guidance for street vendors is needed to socialize the rules regarding street vendors so that there is an arrangement that can run better. The concept of providing a place, selling place layout harmony can increase the attractiveness for visitors, so as to increase the income of street vendors and for street vendor fees do not mind because the specified retribution amount does not burden the street vendors, besides that the local government is indirectly helped from the levy because it can provide income for the area.

\section{References}

Ali, Faried and Alam, Syamsu. (2012). Government Policy Study. Bandung: PT. Refika Aditama. Azhari, D. (2017). Penataan Pedagang Kaki Lima Pada Pasar Atas Dana Pasar Bawah Kota Bukittinggi. Jom Fisip, Universitas Riau, 4(1), 1-12.

Koespramoedyo, Deddy. (2003). Kalimantan Development Border Area Strategy and Model. Directorate of Special \& Disadvantaged Areas Development Deputy for Regional Autonomy \& Regional Development BAPPENAS, Jakarta.

Mcgee, T.G. and Y.M. Yeung. (1977). Hawkers In Southeast Asian Cities: Planning For The Bazaar Economy. Ottawa: International Development Research Centre.

Permadi, Gilang. (2007). Street Vendors: Your History First, Your Current Destiny. Jakarta: Yudhistira 
Purnawati, L. (2016). Evaluasi Penataan Dan Pemberdayaan Pedagang Kaki Lima Dari Taman Aloon-Aloon Kabupaten Tulungagung. Jurnal Evaluasi Penataan Dan Pemberdayaan Pedagang Kaki Lima, 48-79.

Puspitasari, D. E. (2010). Penataan Pedagang Kaki Lima Kuliner Untuk Mewujudkan Fungsi Tata Ruang Kota Di Kota. Mimbar Hukum, 22, 588-606.

Republik Indonesia. (2010). Undang-Undang Nomor 5 Tahun 2010 Tentang Retribusi Pelayanan Pasar.

Republik Indonesia. (2012). Peraturan Menteri Dalam Negeri Nomor 41 Tahun 2012 Tentang Pedoman Penataan Dan Pemberdayaan Pedagang Kaki Lima.

Siagian, P Sondang. (2008). Strategic Management. Jakarta: Earth Literacy.

Situmorang, D, M. Hapsari, V, R. (2019). Faktor-Faktor yang mempengaruhi Perilaku Belajar Akuntansi di Daerh 3 T. Jurnal Akuntansi, Ekonomi dan Manajemen Bisnis, 7(1), 77-84. Sugiyono. (2013). Metode Penelitian Kuantitatif Kualitatif dan R\&D. Bandung: Alfabeta. Tahir, M. M. (2016). Peran Pemerintah Daerah Dalam Pelaksanaan Penataan Pedagang Kaki Lima Di Pasar Minasamaupa Kabupaten Gowa. Ilmu Pemerintahan, 6(April), 28-41. Umar, Husein. (2004). Metode Riset Ilmu Administrasi. Jakarta: Gramedia Pustaka Utama. Widigdo, P. H., and Zain, M. I. (2013). Karakteristik Sosial Ekonomi Pedagang Kaki Lima di UPTD Pasar Ngemplak Kabupaten Tulungagung. Jurnal Mahasiswa.UNESA. 